\title{
Effect of Different Pre-sowing Seed Treatments on Growth and Seed Quality Parameters of Maize (Zea mays L.)
}

\author{
R. Yaswanth Krishna*, Prashant Kumar Rai, Shailesh Marker and Ramesh Chandra
}

Department of Genetics and Plant Breeding, Naini Agricultural Institute, Sam Higginbottom University of Agriculture, Technology and Sciences, Pryagraj, 211007 U. P., India

*Corresponding author

\section{Keywords}

Priming methods, Magnetic field, Tulsi and Neem leaf extract

Article Info

Accepted:

26 June 2019

Available Online:

10 July 2019

\section{A B S T R A C T}

The experiment was conducted in Post Graduate Laboratory, Department of Genetics and Plant Breeding, Sam Higg in bottom University of Agriculture, Technology and Sciences, Pryagraj (U.P.) during kharif season 2018, in order to standardize the best method of priming specific to Maize (var. HQPM-5). Four methods of priming viz., hydropriming, magnetopriming, halopriming, and organic priming with control (Unprimed) were evaluated by screening different duration $(30,60,90,120$ minutes and 12 hours) and different concentrations $\left(50 \mathrm{mt}, 100 \mathrm{mt}, 2 \%\right.$ and $5 \%$ ) viz., $\mathrm{T}_{0}$-Unprimed (Control), hydropriming - $\mathrm{T}_{1}$-Distilled water (12 hours), magnetopriming- $\mathrm{T}_{2}$-Magnetic field (50 $\left.\mathrm{mt}\right)$ @ 30 minutes, $\mathrm{T}_{3}$-Magnetic field (50 mt) @ 60 minutes, $\mathrm{T}_{4}$-Magnetic field (50 mt) @ 90 minutes, $\mathrm{T}_{5}$-Magnetic field $(50 \mathrm{mt}) @ 120$ minutes, $\mathrm{T}_{6}$-Magnetic field $(100 \mathrm{mt}) @ 60$ minutes, $\mathrm{T}_{7}$-Magnetic field (200 mt) @ 60 minutes, halopriming- $\mathrm{T}_{8}$ - Potassium Chloride (KCl) $2 \%$, organic priming- $\mathrm{T}_{9}$ - Tulsi leaf extract $(5 \%), \mathrm{T}_{10}$ - Neem leaf extract $(5 \%)$. It was found that all the priming treatment showed significance difference with the control and the highest germination percent, seedling length, seedling fresh weight, seedling dry weight, vigour indices were observed formagneto priming - Magnetic field (50 mt) @ 60 minutes. Highest germination was observed in Magnetic field and KCl. Seed priming, its simplicity and no requirement for expensive equipment and chemical could be used as a simple method for overcoming related to a poor germination and seedling establishment and helps in sustaining agriculture and cost effective and economic, non-toxic, ecofriendly sources.

\section{Introduction}

Maize (Zea mays L) is one of the most important cereal crops of the world. It ranks third after wheat and rice. It is a member of grass family graminae $(2 n=20)$, tribe Maydeae. This cereal is referred to as "Miracle Crop" and "Queen of the Cereals" due to its high productivity (lkramullah et al., 2011).
Presently maize is cultivated in 165 countries on 184 million hectares (ha), and has a production of 1,016 million tons (t) and productivity of $5.52 \mathrm{t} / \mathrm{ha}$ globally.

In terms of production, India, with 9.4 million ha, ranks fourth globally, after the USA States (35.5 million ha), China (35.3 million ha) and Brazil (15.4 million ha) (Yadav et al., 2014). 
There is a strong possibility to develop hybrids having higher yielding ability and nutritionally superior and industrially important with respect to high starch, protein and oil content (Gouthum et al., 2003) However to overcome the above problem, the Maize breeders have developed Quality Protein Maize (QPM) by incorporating O2 (opaque-2) mutant gene, which is particularly responsible for enhancing lysine and tryptophan content of maize endosperm protein. The seeds and cobs are used as basic raw Material in Various industries the seeds are processed and made for needed preparations, flakes, girts and pops for human consumptions (Kumar and Rai, 2006).

Pre-sowing treatments of their seeds for ensuring their earlier, successful germination. This will help people to minimize their production cost of seedlings on a broad scale. A considerable body of evidences suggests that pre-sowing treatments strongly enhance the germination process (Hossain et al., 2005; Palani et al., 1996).

Priming is the method used to improve stand establishment in several crops. Seed priming is a process in which seeds are imbibed either in water or in osmotic solution or combination of solid matrix carrier and water in specific proportion followed by drying before radical emergence. It is reported that seed priming is one of the most important developments to help rapid and uniform germination and emergence of seeds and to increase seed tolerance to adverse environmental conditions (Heydecker et al., 1973; Harris et al., 1999). Haloprimingwas conducted with salt $\mathrm{NaCl}$ $1 \%$ solution and $\mathrm{CaCl}_{2} \quad 1 \%$ solution concentration. Seeds were soaked $25^{\circ} \mathrm{C}$ for 14 hour in Petri plates. After dried and at room temperature and subjected to germination test, done at $25^{\circ} \mathrm{C}$ for $14 \mathrm{hrs}$. Evaluated the effects of $\mathrm{NaCl}$ priming with $\mathrm{KNO}_{3}$ on the germination traits and seedling growth of four Helianthus annuиs L. cultivars under salinity conditions and reported that germination percentage of primed seeds was greater than that of un-primed seeds Bajehbaj (2010).

Seed priming has presented promising, and even surprising results, for many seeds including the cereal seeds Bradford, (1986). In which organic priming plant extract is used after that drying, such as Neem leaf extract, Curi leaf extract, Tulsi leaf extract, Neem seed kernel powder for maize. A higher concentration of this powder $(10 \% \mathrm{w} / \mathrm{w})$ was found effective over long period of time Sharma, (1995). So keeping these aspects in view the present experiment entitled Effect of pre-sowing seed treatments on growth, seedling, yield and its attributing characters of Maize (Zea mays L.). Was carried out with following objectives:

To determine the effect of pre-sowing seed treatments of botanicals, magnetic and chemicals on seedling parameters of Maize.

To find out the suitable pre-sowing seed treatment for Maize seeds

\section{Materials and Methods}

The experiment was conducted in Post Graduate Laboratory, Department of Genetics and Plant Breeding, Sam Higginbottom University of Agriculture, Technology and Sciences, Pryagraj (U.P.) maize (var. HQPM5). The treatments used at different concentrations for priming were $\mathrm{T}_{0}$-Unprimed (Control), hydropriming - $\mathrm{T}_{1}$-Distilled water (12 hours), magnetopriming- $\mathrm{T}_{2}$-Magnetic field (50 mT) @30 minutes, $\mathrm{T}_{3}$-Magnetic field (50 mT) @60 minutes, $\mathrm{T}_{4}$-Magnetic field (50 mT) @90 minutes, $\mathrm{T}_{5}$-Magnetic field (50 mT) @ 120 minutes, $\mathrm{T}_{6}$-Magnetic field (100 mT) @ 60 minutes, $\mathrm{T}_{7}$-Magnetic field (200 mT) @60 minutes, halopriming$\mathrm{T}_{8}-$ Potassium Chloride (KCl) 2\%, organic 
priming- $\mathrm{T}_{9^{-}}$Tulsi leaf extract $(5 \%), \mathrm{T}_{10-}$ Neem leaf extract $(5 \%)$. After cleaning and grading, the seeds were soaked in respective priming solutions at different volume of seeds for 30, 60, 90, 120 minutes and twelve hours. Then the seeds were air dried under the shade to bring back to their original moisture content and used for sowing.

\section{Preparation of solution}

For the preparation of solution of the $\mathrm{Kcl}$, Ten gram chemical will be taken in a beaker. The chemicals were added in $1000 \mathrm{ml}$. of distilled water with constant stirring. The volume of solution will finally constituted to one litter, then it became $1 \%$ stock solution of $\mathrm{Kcl}$ chemical.

For the preparation of solution of the Botanicals, Ten gram of each chemical will be taken in a beaker. These botanical leaf extract were added in $1000 \mathrm{ml}$. of distilled water with constant stirring. The volume of solution will finally constituted to one litter, then it became $1 \%$ stock solution of each chemical. The flasks containing chemicals were covered with muslin cloth to avoid any contamination. For neem leaf extract exactly weigh fifty gram of leaf powder using weighing balance and dissolved in $1000 \mathrm{ml}$ of distilled water which was measured already in the beaker to make $5 \%$ leaf extract.

\section{Soaking in the solution}

After preparation of solution of KCL and Botanicals, maize seeds will be soaked in required solution for 12 hour and in magnetic field (mT) 30, 60, 90, 120 minutes at $25^{\circ} \mathrm{C}$ temperature. Untreated seed is called as control. After $12 \mathrm{hrs}$ of soaking the solution will be drained out from the beaker and presoaked $24 \mathrm{hrs}$ at $25^{\circ} \mathrm{C}$ temperature will be air dried to original weight and then placed for germination in laboratory under controlled condition.

\section{Magnetic field}

An electromagnetic field generator "Testron EM-20" with variable static magnetic field (SMF) strength (50 to $500 \mathrm{mT}$ ) with a gap of $5 \mathrm{~cm}$ between pole pieces was fabricated. A D.C. power supply $(80 \mathrm{~V} / 10 \mathrm{~A})$ with continuously variable output current was used for the electromagnet. A digital gauss meter model DGM-30 operating on the principle of Hall Effect monitored the field strength produced in the pole gap. The probe is made of Indium arsenide crystal and is encapsulated to a non- magnetic sheet of $5 \mathrm{~mm} \times 4 \mathrm{~mm} \times 1$ $\mathrm{mm}$ and could measure 0-2 Tesla with fullscale range in increments of 5 MT. By regulating the current in the coils, desired strength of SMF was monitored, which was measured by a Gauss meter. The strength and duration was standardized for maximum enhancement of germination and vigour of seeds.

The observation on the characters viz., Germination percent (ISTA, 2004), Root length $(\mathrm{cm})$, Shoot length $(\mathrm{cm})$, Seedling length $(\mathrm{cm})$, Seedling Fresh weight $(\mathrm{g})$, Seedling dry weight (g), Seedling Vigour index-I, Seedling Vigor index-II (Baki and Anderson, 1973) were recorded. The experimental data recorded were subjected to statistical analysis for calculating analysis of variance, range, mean, critical difference and coefficient of variation (Fisher, 1936).

\section{Germination per cent $(\%)$}

Germination test was conducted by adopting between blotter paper methods as described by ISTA procedures.

Number of seeds germinated Germination $(\%)=-\times 100$ Number of seeds put for germination

For taking observation regarding seed germination, 100 seeds were kept blotting paper (BP method). The paper folds were kept 
in germination in an upright position at constant temperature $25^{\circ} \mathrm{C}+2{ }^{\circ} \mathrm{C}$ and $80 \% \mathrm{RH}$ (ISTA, 2004). Four replications were made for each treatment with First count was taken on $4^{\text {th }}$ day and Final count made after 7 days of treatment.

\section{Root, shoot and seedling length $(\mathrm{cm})$}

For recording seedling length, 10 seedlings from each sample were taken randomly. The length of roots, shoots and total seedling were measured. To find out the average length of roots, shoots and total seedling of the sample, mean often seedlings were taken.

\section{Seedling fresh weight}

For recording seedling fresh weight, 10 seedlings from each sample were taken randomly. The fresh weight of seedlings was weighted on electronic balance.

\section{Seedling dry weight (gm)}

For taking the observation of seedling dry weight, 10 seedlings were dried $100^{\circ} \mathrm{C}$ temperatures for 1hours. The dried seedlings were weighted on electronic balance.

\section{Seedling vigour index-I (gm)}

Seedling vigor index was calculated by adopting the method suggested By Abdul Baki and Anderson (1973).

Seedling Vigor Index- I= Germination (\%) $\mathrm{x}$ Total seedling length $(\mathrm{cm}$.

\section{Seedling vigour index-II}

Vigor index in terms of mass is determined by the multiplication of germination percentage with seedling dry weight on the day of final count.

Seedling Vigor index-II = germination $(\%) \mathrm{X}$ seedling dry weight

\section{Results and Discussion}

According to the results, all studied traits were affected by the treatments and there was completely significant difference between control (non-primed seeds) and primed seeds (Table 1).

All seedling characters viz. Germination percent, Root length $(\mathrm{cm})$, Shoot length $(\mathrm{cm})$, Seedling length $(\mathrm{cm})$, seedling fresh weight (g), seedling dry weight (g), Seedling Vigour index-I, Seedling Vigor index-II were affected by Magnetic field (50 mT) @60 minutes significantly recorded maximum where found in lowest control (Table 2).

Significantly higher germination percent $(98.00 \%)$ reported in treatment $\mathrm{T}_{3}$-Magnetic field (50 mT) @ 60 minutes followed by $\mathrm{T}_{2^{-}}$ Magnetic field (50 mT) @ 30 minutes $(97.25 \%)$ andT $_{8}-$ Potassium Chloride $(\mathrm{KCl})$ $2 \%(96.00 \%)$. Minimum germination percent recorded by $\mathrm{T}_{0}(88.75 \%)$ unprimed with control. Alexander and Doijode (1995) reported that pre-germination treatment improved the germination and seedling vigour of low viability rice and onion seeds. Carbonell et al., (2000) found that magnetic treatment produced a biostimulation of the germination of rice seeds. Aladjadjiyan (2002); Podlesni et al., (2004) published the positive effect of magnetic treatment on the germination and emergence of two broad bean cultivars.

Maximum root length $(12.09 \mathrm{~cm})$ recorded by $\mathrm{T}_{3}$-Magnetic field $(50 \mathrm{mT})$ @ 60 minutes followed by $\mathrm{T}_{2}$-Magnetic field (50 mT) @ 30 minutes $(11.63 \mathrm{~cm}) \quad$ andT $_{8}-$ Potassium Chloride $(\mathrm{KCl}) 2 \%(11.01 \mathrm{~cm})$. Minimum root length recorded by $\mathrm{T}_{0}$ unprimed with control $(7.35 \mathrm{~cm})$. Maximum shoot length $(7.22 \mathrm{~cm})$ recorded by $\mathrm{T}_{3}$-Magnetic field $(50$ mT)@60 minutes followed by $\mathrm{T}_{2}$-Magnetic field (50 mT) @ 30 minutes $(6.65 \mathrm{~cm}) \operatorname{andT}_{8}-$ 
Potassium Chloride $(\mathrm{KCl}) 2 \%(6.06 \mathrm{~cm})$. The shortest shoot length founded in $\mathrm{T}_{0}$ unprimed with control $(3.15 \mathrm{~cm})$. Maximum seedling length $(19.31 \mathrm{~cm})$ recorded by $\mathrm{T}_{3}$-Magnetic field $(50 \mathrm{mT}) @ 60$ minutes followed by $\mathrm{T}_{2-}$ Magnetic field (50 mT) @ 30 minutes(18.28 $\mathrm{cm})$ and $\mathrm{T}_{8}-$ Potassium Chloride $(\mathrm{KCl}) 2 \%$ $(17.07 \mathrm{~cm})$.Shortest seedling length recorded in $\mathrm{T}_{0}$ unprimed with control $(10.50 \mathrm{~cm})$. Also found that root and shoot lengths increased in seeds due to magneto-priming as compared to non-primed seeds. Florez et al., (2004) observed an increase for the initial growth stages and an early sprouting of rice seeds exposed to 25 and $50 \mathrm{mT}$ stationary magnetic field. In wheat, Pittman and Ormrod (1970) reported that the seedlings grown from magnetically treated seed $(80 \mathrm{mT})$ absorbed more moisture, respired more slowly, released less heat energy and grew faster than the untreated controls. Kavi (1977)found that seeds exposed to a magnetic field absorbed more moisture and enhance seedling length of ragi. Martinez et al., (2000, 2002) observed similar effects on wheat and barley seeds magnetically treated. All these causes increased in seed root and shoot length which ultimately increased the total seedling length.

Maximum seedling fresh weight $(14.69 \mathrm{gm})$ reported by $\mathrm{T}_{3}$-Magnetic field (50 mT) @ 60 minutes followed by $\mathrm{T}_{2}$-Magnetic field (50 $\mathrm{mT}) @ 30$ minutes $(14.16 \mathrm{gm})$ and $\mathrm{T}_{8}$ Potassium Chloride (KCl) 2\% (13.71 gm). Lowest value of seedling fresh weight founded in $\mathrm{T}_{0}(9.76 \mathrm{gm})$ with unprimed control. Maximum seedling dry weight (4.03gm) recorded by $\mathrm{T}_{3}$-Magnetic field (50 $\mathrm{mT}) @ 60$ minutes followed by $\mathrm{T}_{2}$-Magnetic field (50 mT)@30 minutes (3.42 gm) and $\mathrm{T}_{8}-$ Potassium Chloride (KCl) 2\% (3.03 gm). Lowest value of seedling dry weight founded in $\mathrm{T}_{0}(1.06 \mathrm{gm})$ with unprimed control. Magnetic field treatment showed that positive effect on testing parameters seedling fresh weight, seedling dry weight, seedling vigor.
Similar results were obtained by Kubisz et al., (2012), they observed that clear differences in the fresh mass of seedling, longer radicals and heavier seedling than the ones from the control on the onion seeds exposed to magnetic field. Waleed et al., (2013) showed that dry weight of root and radical increased by 0.52 and $43 \%$, respectively when exposed wheat seeds to $(50 \mathrm{mT} / 30 \mathrm{~min})$. Azita and Majd (2009) showed that the Lentil seedlings from seeds magnetically pretreated grew taller and heavier (mass) than untreated controls.

Maximum seedling vigour index-I (1893.83) recorded by $\mathrm{T}_{3}$-Magnetic field $(50 \mathrm{mT})$ @ 60 minutes followed by $\mathrm{T}_{2}$-Magnetic field (50 $\mathrm{mT}$ ) @ 30 minutes (1778.34) and $\mathrm{T}_{8-}$ Potassium Chloride (KCl) 2\% (1639.61). Lowest value of vigour index-I founded in $\mathrm{T}_{0}$ (931.99) with unprimed control. The higher seed vigour index I under magnetic field 50 mT compared to control is due to their promotional effects on seed germination and seedling length. Vashisth and Nagarajan (2008a \& b, 2010) reported significant increase in germination, seedling vigour and shoot growth in maize, chickpea and sunflower seeds exposed to SMFs. Magnetic field treatment of seeds leads to acceleration of plants growth and vigour index (Kordas, 2002). Similar effect on wheat crop observed by Ahmad et al., (2010).

Maximum seedling vigour index-II (395.52) recorded by $\mathrm{T}_{3}$-Magnetic field (50 mT) @ 60 minutes followed by $\mathrm{T}_{2}$-Magnetic field (50 mT) @ 30 minutes (333.00) and $\mathrm{T}_{8-}$ Potassium Chloride (KCl) 2\% (290.98). Lowest value of vigour index-II founded in $\mathrm{T}_{0}$ (94.08) with unprimed control. The improvement in vigour of normal/low-vigour seed might be due to reserve mobilization of food material, activation and re-synthesis of some enzymes DNA and RNA synthesis start during hydro-priming and magneto-priming. Numerous studies have demonstrated 
enhanced growth and vigour mass, when tomato seeds were treated with MF (Boe et al., 1968). Similar finding on tomato seeds by
(De Souza et al., 2006; Martinez et al., 2009; Feizi et al., 2012).

Table.1 Analysis of variance for 8 seedling characters in maize

\begin{tabular}{|c|c|c|c|}
\hline S.No. & Characters & \multicolumn{2}{|c|}{ Mean sum of squares } \\
\cline { 3 - 4 } & & $\begin{array}{c}\text { Treatments } \\
(\mathbf{d f}=\mathbf{6})\end{array}$ & $\begin{array}{c}\text { Error } \\
(\mathbf{d f = 2 1})\end{array}$ \\
\hline $\mathbf{1 .}$ & Germination Percentage & $33.09^{* * *}$ & 1.30 \\
\hline $\mathbf{2 .}$ & Root Length & $10.14^{* * *}$ & 0.15 \\
\hline $\mathbf{3 .}$ & Shoot Length & $7.14^{* * *}$ & 0.06 \\
\hline $\mathbf{4 .}$ & Seedling Length & $34.20^{* *}$ & 0.19 \\
\hline $\mathbf{5 .}$ & Seedling Fresh Weight & $11.08^{* * *}$ & 0.16 \\
\hline $\mathbf{6 .}$ & Seedling Dry Weight & $4.199^{* * *}$ & 0.007 \\
\hline $\mathbf{7 .}$ & Seedling Vigour Index I & $39845.55^{* * *}$ & 2243.03 \\
\hline $\mathbf{8 .}$ & Seedling Vigour Index II & $42273.79^{* *}$ & 91.74 \\
\hline
\end{tabular}

** significant at $5 \%$ level of significance

Table.2 Mean performance of maize for 8 seedling characters

\begin{tabular}{|c|c|c|c|c|c|c|c|c|c|}
\hline $\begin{array}{l}\dot{Z} \\
\dot{\boldsymbol{Z}}\end{array}$ & & ه & 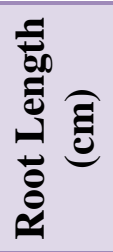 & 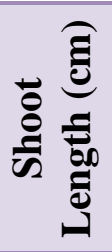 & 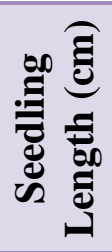 & 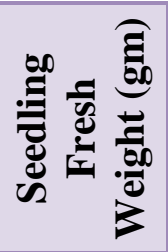 & 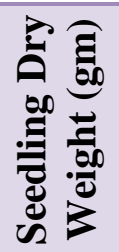 & 哭 & 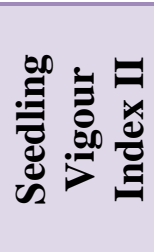 \\
\hline 1 & $\mathbf{T}_{\mathbf{0}}$ & 88.75 & 7.35 & 3.15 & 10.50 & 9.76 & 1.06 & 931.99 & 94.08 \\
\hline 2 & $\mathbf{T}_{1}$ & 90.50 & 7.85 & 3.47 & 11.32 & 10.07 & 1.11 & 1024.88 & 101.14 \\
\hline 3 & $\mathbf{T}_{2}$ & 97.25 & 11.63 & 6.65 & 18.28 & 14.16 & 3.42 & 1778.34 & 333.00 \\
\hline 4 & $\mathbf{T}_{\mathbf{3}}$ & 98.00 & 12.09 & 7.22 & 19.31 & 14.69 & 4.03 & 1893.83 & 395.52 \\
\hline 5 & $\mathbf{T}_{4}$ & 95.50 & 10.05 & 5.12 & 15.17 & 12.76 & 2.03 & 1449.49 & 193.81 \\
\hline 6 & $\mathbf{T}_{5}$ & 95.00 & 10.60 & 5.77 & 16.37 & 13.32 & 2.59 & 1555.98 & 246.28 \\
\hline 7 & $\mathbf{T}_{6}$ & 94.75 & 9.72 & 4.79 & 14.51 & 12.09 & 1.79 & 1374.99 & 169.61 \\
\hline 8 & $\mathbf{T}_{7}$ & 93.75 & 9.11 & 4.31 & 13.42 & 11.61 & 1.48 & 1259.32 & 139.47 \\
\hline 9 & $\mathbf{T}_{8}$ & 96.00 & 11.01 & 6.06 & 17.07 & 13.71 & 3.03 & 1639.61 & 290.98 \\
\hline 10 & $\mathbf{T}_{9}$ & 91.50 & 8.15 & 3.86 & 12.01 & 10.80 & 1.23 & 1099.44 & 112.56 \\
\hline 11 & $\mathbf{T}_{10}$ & 92.50 & 8.44 & 4.06 & 12.50 & 11.18 & 1.31 & 1156.05 & 121.99 \\
\hline \multicolumn{2}{|c|}{ Grand Mean } & 93.95 & 9.63 & 4.95 & 14.58 & 12.19 & 2.10 & 1378.54 & 199.86 \\
\hline \multicolumn{2}{|c|}{ C.D. $(5 \%)$} & 1.64 & 0.57 & 0.35 & 0.63 & 0.59 & 0.12 & 68.13 & 13.77 \\
\hline \multicolumn{2}{|c|}{ SE(m) } & 0.57 & 0.19 & 0.12 & 0.22 & 0.20 & 0.04 & 23.68 & 4.78 \\
\hline \multicolumn{2}{|c|}{ C.V. } & 1.21 & 4.12 & 4.98 & 3.02 & 3.37 & 4.24 & 3.43 & 4.39 \\
\hline
\end{tabular}


Germination per cent $(98.00 \%)$ was highest in Magnetic field (50 mT) @60 minutes followed by Magnetic field (50 mT) @30 minutes $(97.25 \%)$ and found to be lowest in unprimed (control) seeds (88.75\%). Root length, Shoot length and Seedling length $(12.09 \mathrm{~cm}, \quad 7.22 \mathrm{~cm}$ and $19.31 \mathrm{~cm})$ respectively were highest in Magnetic field (50 mT) @60 minutes seeds and lowest in unprimed (control) seeds $(7.35 \mathrm{~cm}, 3.15 \mathrm{~cm}$ and $10.50 \mathrm{~cm}$ ) respectively. However seedling attributes were also positively influenced by magnetopriming, highest seedling fresh weight $(14.69 \mathrm{gm})$ and seedling dry weight $(4.03 \mathrm{gm})$ was observed in Magnetic field (50 mT) @60 minutes seeds followed by Magnetic field (50 mT) @ 30 minutes seeds having seedling fresh weight and seedling dry weight (14.16 gm and $3.42 \mathrm{gm}$ ) respectively and found to be lowest in unprimed (control) seeds $(9.76 \mathrm{gm}$ and $1.06 \mathrm{gm})$ respectively.

Seedling vigour indices were also positively influenced by magnetopriming, highest vigour index-I was observed in Magnetic field (50 mT) @ 60 minutes seeds (1893.83) and found to be lowest in unprimed (control) seeds (931.99) and highest vigour index-II was observed in Magnetic field (50 mT) @60 minutes seeds (395.52) and found to be lowest in unprimed (control) seeds (94.08).

In conclusion, priming increases the germinability and vigour of maize seeds, significantly all laboratory parameters. Magnetopriming (MT 50), Halopriming ( $\mathrm{KCl}$ ) significantly increased the germination per cent and other seedling characters of maize. Magnetopriming with Magnetic field (50 mT) @ 60 minutes showed maximum increase in germinability and vigour and showed maximum increase in germination. Priming of the maize seeds for $30,60,90,120$ minutes and $12 \mathrm{hrs}$, in which Magnetic field $(50 \mathrm{mT})$ @ 60 minutes best result to enhanced germinability, vigour and seedling chracters.
These conclusions are based on the results of six months investigation and therefore further investigation is needed to arrive at valid recommendations.

\section{Acknowledgement}

The author are thankful to the Hon'ble Vice Chancellor, Directorate of research, Head, All teaching and non-teaching staff Department of Genetics and Plant Breeding, Sam Higginbottom University of Agriculture, Technology and Sciences Prayagraj, U. P., for providing all necessary facilities and support.

\section{References}

Ahmad G, Sharafi S, Abbasdokht H (2010).Effect of magnetic field on seed germination of two wheat cultivars. World Acad. Sci. Eng. Technol. 44:8-23.

Aladjadjiyan, A., (2002). Study of the influence of magnetic field on some biological characteristics of Zea mays. J. Central Eur. Agric. 3 (2), 89-94.

Alexander, M.P., Doijode, S.D., (1995). Electromagnetic field, a novel tool to increase germination and seedling vigour of conserved onion (Allium cepa L.) and rice (Oryza sativa L.) seeds with low viability. Plant Genet. Resour. Newslett. 104, 1-5.

AzitaSh, Ahmad M (2009).Effect of Magnetic Fields on Growth and Antioxidant Systems in Agricultural Plants PIERS Proceedings, Beijing, China, March 23-27.

Bajehbaj AA. (2010). The effects of $\mathrm{NaCl}$ priming on salt Tolerance in Sunflower Germination and Seedling grown under salinity conditions. African Journal of Biotechnology 9 (12), 1764-1770.

Baki A, Anderson JD. (1973). Vigor determination in Soybean seed by multiple criteria. Crop Sci. 13: 630- 
633.

Boe, A.A., Do, J.Y. and Salunkhb, D.K. (1968). Tomato ripening: Effects of light frequency, magnetic field, and chemical treatments Eco. Bot. 22: 124-134.

Bradford K.J. (1986). Manipulation of seeds water relation via osmotic priming to improve germination under stress condition. Horticulture science, 59(2):672-676.

Carbonell, M.V., Mart'inez, E., Amaya, J.M., (2000). Stimulation of germination in rice (Oryza sativa L.) by a static magnetic field. Electro Magnetobiol. 19 (1), 121-128.

Chandel, U. and Mankotia, B.S. (2014). Combining ability in local and CIMMYT inbred lines of maize (Zea mays L.) for grain yield and yield components using line $\mathrm{x}$ tester analysis. SABRO Journal of Breeding and Genetics. 46(2): 256-264.

De Souza, A., Garci, D. and Sueiro, L. (2006). Presowing magnetic treatments of tomato seeds increase the growth and yield of plant. Bioelectromagn. 27: 247-257.

Feizi, H., Sahabi, H., Rezvani, P., Parviz, R.M., Shahtahmassebi, N., Galehgir, O. and Amirmorad, S. (2012). Impact of intensity and exposure duration of magnetic field on seed germination of tomato (Lycopersicon esculentum L.). Not. Sci Biol. 4: 116-120.

Fisher, R.A. (1936). The correlation between relative on the supposition of genotypes grown in Kumaun Himalaya, Indian Journal Genetics. 66 (1): 37-38.

Florez, M., Carbonell, M.V., Martinez, E., (2004). Early sprouting and first stages of growth of rice seeds exposed to a magnetic field. Electromagnetobiol. Med. 23 (2), 167-176.
Gautam. A.S. (2003). Combining ability studies for grain yield and other agronomic characters in inbred lines of maize (Zea mays L). Crop Research, Hisar, 26(1): 482-485.

Harris D., Joshi A., Khan P.A., Gothkar P. and Sodhi P.S. (1999). On-farm seed priming in semi-arid agriculture. Development and evaluation in maize, rice and chickpea in India using participatory methods. Experimental Agriculture, 35: 15-29.

Heydecker, W., Higgins, J., Gulliver R. L. (1973).Accelerated germination by osmotic seed treatment. Nature, 246: 42-44.

Ikramullah, Iftikhar, H. K., Muhammad, N and Mohammad, K. N. S, (2011). Heterotic effects for yield and protein content in white quality protein maize Sarhad Journal Agriculture 27 (3): 5256.

ISTA (2004). International Seed Testing Association (2004) International rules for seed testing. ISTA, Zürich: P. 206.

Kavi, P.S., (1977). The effect of magnetic treatment of soybean seed on its moisture absorbing capacity. Sci. Cult. 43, 405-406.

Kordas L (2002). The effect of magnetic field on growth, development and the yield of spring wheat, polish. J. Environ. Stud. 11(5): 527-530.

Kubisz L, Holubowicz R, Gauza M, Li H, Hojan-Jezierska D, Jaroszyk F (2012). Effect of low frequency magnetic field on germination of onion (Allium cepa L.) seeds. Acta Physica Polonica A, P. 121, No. 1-A.

Martinez, E., Carbonell, M.V., Amaya, J.M., (2000). A static magnetic field of 125 $\mathrm{mT}$ stimulates the initial growth stages of barley (Hordeum vulagare L.). Electro- Magnetobiol. 19 (3), 271277.

Martinez, E., Carbonell, M.V., Florez, M., 
(2002). Magnetic biostimulation 'of initial growth stages of wheat (Triticum aestivum L.). Electromagn. Biol. Med. 21 (1), 43-53.

Martinez, E., Carbonell, M.V., Flórez, M., Amaya, J.M. and Maqueda, R. (2009). Germination of tomato seeds (Lycopersicon esculentum L.) under magnetic field. Intl. Agrophys. 23: 4549.

Pittman, U. J., and Ormrod, D. P. (1970). Physiological and chemical features of magnetically treated winter wheat seeds and resultant seedlings. Canadian journal of plant science, 50(3), 211-217.

Podlesni, J., Pietruszewski, S., Podlesna, A., (2004). Efficiency of the magnetic treatment of broad bean seeds cultivated under experimental plot conditions. Int. Agrophys. 18 (1), 6571.

Prasanna, B.M., Vasal, S. K., Kassahun, B. and Singh, N. N. (2001). Quality protein maize. Current Sciences.10: 1308-1309.

Prashant Kumar Rai, Girjesh Kumar and K.K Singh (2011) Influence of packaging material and storage time on seed germination and chromosome biology of inbreed lines of maize (Zea mays. L). Journal of Agricultural Technology.7 (6):1765-1774

Rajitha, A., Ratna Babu, D., Lal Ahamed, M and Srinivasa Rao, V.(2014). Heterosis and combining ability for grain yield and its components in maize (Zea mays L.). Journal of Research. ANGRAU. 39(3): 6-15.

Sharma, R. IC. (1995). Neem leaf powder and cobash against Rhyzopertha dominica $(\mathrm{F})$, in stored maize. Indian Journal of Entomology, 57: 15-17.

Vashisth, A. and Nagarajan, S. (2008a). Effect of magnetic field on seeds performance of diverse crop species. Indian J. Agric. Sci. 78:60-63.

Vashisth, A. and Nagarajan, S. (2008b). Exposure of seeds to static magnetic field enhances germination and early growth characteristics in chickpea (Cicer arietinum L.). Bioelectromagn. 29: 571- 578.

Vashisth, A. and Nagarajan, S. (2010). Effect on germination and early growth characteristics in sunflower (Helianthus annuus L.) seeds exposed to static magnetic field. J. Plant Physiol. 167: 149- 156.

Waleed AJ, Riyadh CA, Hussein FH (2013). Effect of magnetic field on seed germination of Triticum aestivum. World J. Agric. Sci. 5:168- 171.

Yadav, O.P., Karjagi, G.C., Kumar, B., Jat, S.L., Chawla, J.S., Kaul, J., Huda, K.S., Kumar, P., Yadav, P. and Dhillon, B.S. (2014) Maize Improvement in India. 12th Asian Maize Conference and Expert Consultation on "Maize for Food, Feed, Nutrition and Environmental Security", Bangkok, 30 October-1 November 2014.

\section{How to cite this article:}

Yaswanth Krishna, R., Prashant Kumar Rai, M. Ramesh Chandra and Veldandi Ajith. 2019. Effect of Different Pre-sowing Seed Treatments on Growth and Seed Quality Parameters of Maize (Zea mays L.). Int.J.Curr.Microbiol.App.Sci. 8(07): 2826-2833. doi: https://doi.org/10.20546/ijcmas.2019.807.353 